AGRICULTURE AND BIOLOGY JOURNAL OF NORTH AMERICA

ISSN Print: 2151-7517, ISSN Online: 2151-7525, doi:10.5251/abjna.2011.2.5.848.859

(C) 2011, ScienceHu $\beta$, http://www.scihub.org/ABJNA

\title{
Termite assemblage structure on Grazing lands in Semi-arid Nakasongola
}

\author{
Swidiq Mugerwa ${ }^{12}$, Moses Nyangito ${ }^{1}$, Denis Mpairwe $^{3}$, Chris Bakuneeta ${ }^{3}$, John \\ Nderitu $^{1}$ and Emmanuel Zziwa ${ }^{13}$ \\ ${ }^{1}$ Department of LARMAT, P. O. Box 30197, University of Nairobi, Kenya. \\ ${ }^{2}$ National Livestock Resources Research Institute, P. O. Box 96, Tororo, Uganda. \\ ${ }^{3}$ Department of Animal Science, Makerere University, P. O. Box 7062, Kampala, \\ Uganda. \\ Corresponding author: Swidiq Mugerwa, E-mail: swidiqk@yahoo.com, Tel: \\ +256782660295 . \\ ABSTRACT
}

Termites are regarded as the primary cause of vegetation denudation in semi-arid Nakasongola, Uganda. Despite their damage to ecosystem functioning, there have been little efforts devoted to the description of the termite assemblage structure in the area. The study therefore intended to describe the termite assemblage structure with the intension to develop sustainable termite management strategies. The survey yielded 16 termite species from eight genera, three sub-families and one family. Species from the sub-family Macrotermitinae constituted $69 \%$ of the total number of species sampled. Members from the genus Macrotermes were the dominant species and constituted 38\% of the total number of species sampled. The assemblage comprised of two feeding groups namely Group II and Group IV, with most of the species belonging to Group II. Most of the species were noted to nest in epigeal and hypogeal nests with a few species nesting in wood. Vegetation cover categories were noted to influence species richness. Highest species richness (14 species) occurred in sparse vegetation category followed by dense category (11) and the least (8 species) occurring on bare ground. The termite assemblage of Nakasongola was dominated by Macrotermes species which largely forage on litter and nest in epigeal mounds.

Keywords: Composition, Diversity, Feeding-group, Nesting-sites

\section{INTRODUCTION}

Termites are occasionally associated with severe damage to rangeland vegetation, particularly, in degraded arid and semi-arid ecosystems (Pearce et al., 1995; Micheal, 2000). Throughout tropical Africa, several species of Macrotermitinae consume grass litter as a significant part of their diet and the most common of these species belong to the genera Macrotermes, Odontotermes and Pseudacanthotermes (Wood, 1991). Typical foraging is characterized by subterranean galleries leading to surface foraging holes from which termites emerge to remove dead grass and grass litter under cover of constructed soil sheeting. Termite foraging is particularly obvious during the dry season when bare rangeland can have up to 55 foraging holes per $\mathrm{m}^{2}$ (Cowie and Wood, 1989). In Nakasongola District of Uganda, termites have been reported to cause enormous reduction of the herbaceous (grasses and forbs) component of the vegetation and partly contributing to formation and expansion of bare surfaces (Sekamatte, 2001; NEMA, 2007). Consequently, the herders are faced with reduced feed availability, poor animal performance, high livestock mortalities and eventually high levels of poverty among pastoral communities. Through removal of the sparse herbaceous vegetation, termites have also contributed to distortion of the complex ecological interactions between grasses and woody species leading to encroachment of grazing lands with shrubs. Mugerwa et al. (2008) noted that termites were the major barrier to pasture restoration on degraded bare patches in Nakasongola due to severe destruction of reseeded seedlings. Cowie and Wood (1989) also reported that Psedocanthotermes species were associated with significant reduction in grass cover during dry periods, while Micheal (2000) observed that pestiferous termite species consumed over $60 \%$ of standing grass biomass. Termites have also been reported to cause severe damage on woody species. Farmers in Nakasongola reported that Combretum collinum, Combretum molle, and 
Acacia hockii were the most susceptible woody species leading to their decline from the ecosystem (Mugerwa et al., unpublished).

Despite the enormous damage to ecosystem function in semi-arid Nakasongola, there has been little effort devoted to the documentation of termite community inventories (Okwakol and Sekamatte, 2007; Nyeko and Olubayo, 2007). At a given site the composition of a local termite assemblage will govern the overall impacts of termites on ecosystem processes (Lavelle et al., 1997; Jones \& Prasetyo, 2002). This is because most termite assemblages are made up of species that represent a diverse range of feeding (e.g. wood, soil, grass) and nesting (e.g. mounds, hypogeal and arboreal nests, nests in wood) strategies (i.e. different 'functional groups'). Consequently different species and groups of species are likely to have different ecological effects on ecosystem components (Dawes-Gromadzki 2005).

Detailed knowledge of local species diversity as well as the diversity of functional groups of termites (different groups of species that have different ecological strategies, e.g. different feeding habits) is critical (Dawes-Gromadzki, 2008). It is a prerequisite for evaluating and quantifying the type and extent of their functional roles in ecosystem processes, i.e. the contributions that different termite species and functional groups make to the regulation of different ecosystem processes. It is also important for the development of sound management practices, e.g. agricultural, grazing and fire management (Abensperg-Traun, 1991; Inoue et al., 2001; DawesGromadzki 2007). Jones (2002) also noted that accurate assessments of structures of termite assemblages are necessary to explain the ecological influence of termites on various sites. Okwakol and Sekamatte (2007) further observed that sustainable management of soil macrofauna in Uganda is constrained by a shortage of information on the activity, behavior and environmental tolerances of many species of this fauna and by the limited understanding of the structural and functional stability of soil fauna communities in general. The study therefore aimed to examine the termite assemblage structure on grazing lands in semi-arid Nakasongola with the intension to develop sustainable termite management strategies as well as to mitigate termiteinduced rangeland deterioration.

\section{MATERIALS AND METHODS}

Description of the study area: The study was conducted on three ranches (Kamukama, Kyapapa and Mandwa ranch) located in Nakasongola District $\left(55^{\circ} 140^{\prime} \mathrm{N}, 32^{\circ} 50^{\prime} \mathrm{E}\right)$ of Uganda. The mean daily maximum temperature in the district is $30^{\circ} \mathrm{C}$. Rainfall range between $500 \mathrm{~mm}-1000 \mathrm{~mm}$ per annum and there are two rain seasons. The main rain season occurs from March-April to June-July while the second rain season follows from August to OctoberNovember. A long dry season occurs from December to February while a short spell comes around JulyAugust.

Kamukama ranch is highly degraded with a large portion of bare surfaces (between 75 to $100 \%$ of total grazing land) that facilitates extra-ordinarily high rates of erosion. Large gullies ranging from 1-3 meters wide and 2-4 meters deep are a common feature on the bare surfaces. The ranch is as well highly infested with termites and the resultant vegetation is partly a product of termite activity. The number of mounds ranged from 33 to 525 with an average of 227 mounds per hectare. We particularly selected the ranch to represent sites that are highly infested with termites. The number of epigeal mounds per hectare (mound density) was used as a proxy for level of termite infestation (Obi and Ogunkunle, 2009). Kyapapa ranch on the other hand is moderately degraded with $25-50 \%$ of grazing land being bare. Smaller numerous gullies ranging from 1-2 meters wide and 1-2 meters deep are also typical of the bare surfaces. The ranch is moderately infested with termites and the number of epigeal mounds ranged from 8 to 300 with an average of 119 mounds per hectare. The ranch was selected to represent sites that are moderately infested with termites while Mandwa ranch (80 epigeal mounds per hectare) was selected to represent sites that are less infested with termites.

Vegetation and soil: The vegetation on the ranches mainly comprised of three vegetation cover types depending on the extent of anthropogenic activities/disturbance on specific ranch sites. The three vegetation cover types included dense vegetation cover, sparse vegetation cover and bare ground. The vegetation cover types were majorly a product of intricate interactions between climatic conditions and anthropogenic activities such as overgrazing, indiscriminate tree cutting and bush burning among others. The dense vegetation cover category on Kamukama ranch mainly comprised of Tarrena graveolens and Acacia species forming 62\%, $3 \%$ of the total woody canopy cover and woody density of 575,125 trees per hectare respectively. The basal vegetation was dominated by Brachiaria species contributing $88 \%$ of the basal cover. The sparse vegetation cover category was dominated by 
Cynodon dactylon and Loudetia kagerensis forming $67 \%$ and $12 \%$ of the species cover. Scattered woody species on the sparse vegetation cover were also dominated by Tarrena graveolens forming $34 \%$ of the woody canopy cover. The bare ground category mainly comprised of highly scattered Harrisonia abyssinica and Tarrena graveolens forming less than $0.5 \%$ canopy cover each. On Kyapapa ranch, the dense vegetation cover category mainly comprised of Securidaca longepedunculata and Terminalia brown forming $70 \%, 7 \%$ of the total woody canopy cover and woody density of 400,300 trees per hectare respectively. The basal vegetation was dominated by Hyperhenia and Brachiaria species contributing 32 and $17 \%$ of the basal cover. The sparse vegetation category was dominated by Brachiaria species forming $50 \%$ of the total species cover. Scattered woody species on the sparse vegetation category were dominated by Securidaca longepedunculata and Terminalia brown forming 16 and $8 \%$ of the canopy cover. The bare ground mainly comprised of highly scattered Tarrena graveolens forming $12 \%$ canopy cover. The dense vegetation category of Mandwa ranch mainly comprised of Tarrena graveolens and Lantana camara forming 31\%, 13\% of the woody canopy cover and woody density of 100,50 trees per hectare respectively. The basal herbaceous vegetation was dominated by Brachiaria species and Imperata cylindrica contributing 33 and $31 \%$ of the basal cover. The sparse category was dominated by Hyperhenia and Brachiaria species forming $63 \%$ and $23 \%$ of the total species cover. The soil $\mathrm{pH}$, soil moisture, soil temperature, bulk density, soil organic matter, nitrogen, phosphorus and potassium on all study sites ranged between 3.6 to $5.8,1.18$ to $15.22,26.7$ to $33.5,1.23$ to $1.7,0.13$ to $1.7,0.01$ to $0.2,1.5$ to 8.7 and 0.17 to 0.46 respectively.

Sampling and classification of termite species : As indicated in the preceding sections, the vegetation of Kamukama and Kyapapa ranches were demarcated into three vegetation cover categories (dense, sparse and bare ground) while that of Mandwa ranch was demarcated into two categories (dense and sparse vegetation cover categories). Termite sampling was conducted between December and January, the period when termite activity and subsequent destruction of vegetation by termites is reported to be severe (NDSOER, 2007). Five plots measuring $50 \mathrm{x}$ $50 \mathrm{~m}$ were randomly established (Dawes- Gromadzki 2008 ) in each vegetation cover category resulting into 15 plots for Kamukama and Kyapapa ranches and 10 plots for Mandwa ranch. Sampling was conducted in
2010 and 2011. Termite samples were collected from each plot following a standardized direct search sampling protocol based on searching different microhabitats (Dawes-Gromadzki 2005). Four trained people searched each plot for $1 \mathrm{~h}$ (a total of 4 person-hours per plot). Searching was conducted in pairs, with the two pairs starting at opposite plot corners. Working back-and-forth across the plot, the first member of each pair examined epigeal and intermediate mounds (new and old so that both the mound builders and secondary occupants were recorded) and foraging trails (carton runways) on trees and surface litter, including those from arboreal nests. The second member examined standing dead wood (including tree stumps), lying dead wood (including logs, branches and twigs), carton sheeting on dead wood and soil beneath rotten wood for termites. For each termite population encountered, representatives of the soldier and worker castes were collected and preserved in $80 \%$ ethanol. Taxonomic identification for collected samples was done at family, sub-family, genus using standard determination keys by Webb (1961) and where possible to species' level using termite records by Sekamatte (2001). Termite species were also classified into nesting groups, and the nesting habit was recorded for each termite collection. The nesting groups were defined as: (1) hypogeal nesting (found below ground); (2) wood nesting (found in woody items); (3) epigeal (in mounds protruding above ground); and (4) arboreal (in tree nests) (Eggleton et al., 2002). Species were also assigned to feeding groups based on in situ observations and gut content classification method by Donovan et al. (2001).

Data collection and analysis: The number of encounters for each termite species was recorded during sampling and the average number of encounters per specie for the two sampling periods (years) was obtained. In order to establish a general picture on the composition of termite assemblage in Nakasongola, the data collected from the various vegetation categories and ranches was pooled before analysis. Species accumulation curves where constructed to calculate the average species richness for all possible combinations of sites (plots) using Biodiversity $\mathrm{R}$ (Oksanen et al., 2005). The same curves were also used to compare species richness among pooled plots for the different vegetation cover categories. The first- and second-order Jackknife, Chao and bootstrap formulae were used to make predictions of the total species richness in the survey area (Kindt and Coe, 2005). Rank abundance curves were constructed to establish the most abundant 
termite species in the survey area using R (2005). In order to establish the influence of vegetation cover categories on termite species composition, the data on species encounters from various vegetation categories was subjected to linear discriminate analysis (Huberty, 1994) in XLSTAT (2008) based on the assumption that within-class covariance matrices are equal. Discriminate analysis was used to establish a set of linear combinations of the quantitative variables (species encounters) that best reveals the differences among the vegetation cover classes.

\section{RESULTS}

Species composition: Termite species representing one family (Termitidae), three sub-families (Macrotermitinae, Termitinae and Nasutitermitinae) and nine genera were identified from 824 termite collections obtained from the three ranches (Table I). Due to the absence of a well developed inventory on termites species in Nakasongola and the widely recognized difficulties in identification of termite species based on morphological characteristics of solider and worker casts, most of the species could not be identified beyond genus level. The sub-family Nasutitermitinae and the genera Trinervitermes and Procubitermes were recorded for the first time. Species from the sub-family Macrotermitinae constituted $69 \%$ of the total number of species sampled. Members from the genus Macrotermes were the dominant species and constituted $38 \%$ of the total number of species sampled. Unlike other species, Trinervitermes oeconomus, Cubitermes spp.3, Microtermes spp and Pseudocanthotermes militaris were very rare species and only occurred in one sampling plot.

The species composition of termite assemblages significantly (Wilks' Lambda test, $p<0.0001$ ) varied among ranches and among vegetation cover categories (Figure 1). Factor 1 (X-axis) and Factor 2 (Y-axis) explained 75.7 and $24.3 \%$ of the total variance due to species composition among vegetation cover categories. The factor loadings for bare, dense and sparse vegetation cover centroids were $-3.255,-0.570$ and 2.664 on factor 1 respectively. The loadings on factor 2 were -1.311 , 1.846 and -0.726 for bare, dense and sparse respectively. The results for factor loadings implied that the composition of termite assemblages for bare and sparse cover categories was distinguished on Factor 1 and the high factor loading of the dense vegetation category implied that it was distinguished from other categories using Factor 2. Termite assemblage structure in the dense vegetation cover category was dominated by Macrotermes herus, Macrotermes spp.4, Cubitermes spp.1 and Ancistrotermes spp. However, Macrotermes herus and Macrotermes spp. 4 were more common than other species in the dense vegetation cover category. It was also noted that Trinervitermes oeconomus only occurred in the dense cover category. Macrotermes billicosus, Macrotermes spp.1, Odontotermes spp.1, Odontotermes spp. 2, Microtermes spp and procubitermes species loaded highly but positively on Factor 1 and therefore the species mostly occurred on sparse vegetation cover and rare on bare ground. However, Cubitermes spp.3 loaded highly but negatively on Factor 1 implying that the species occurred on bare surfaces.

Feeding groups and nesting sites: The termite assemblage comprised of two feeding groups (Table I). Group II (Wood, litter and grass feeders) species dominated, comprising of $75 \%$ of the total species. The rest of the species were true soil feeders. Apart from Trinervitermes oeconomus (specialized grass feeder), all the species that were assigned to Group II are known to be generalist feeders that predominantly feed on litter. Four nesting habitats were represented, with $44 \%$ of the species nesting in epigeal mounds and $31 \%$ of the species nesting in hypogeal nests. Epigeal nesting species included Macrotermes bellicosus, Macrotermes herus, Macrotemes spp.1, Cubitermes spp.1, Cubitermes spp.2, Trinervitermes oeconomus and Procubitermes spp. The number of epigeal mounds ranged from 8 to $525 \mathrm{ha}^{-1}$.

Diversity (species richness and relative abundance of species): A total of 16 species were sampled (Figure 2). However, estimation of the expected number of species in the survey area using Chao, bootstrap, Jackknife-first and second order formulae gave a range of 17 (bootstrap estimate) to 23 (Jackknife-second order estimate) species. Based on this range, 1 to 7 termite species may not have been sampled and the sampled species therefore represent between 70 to $94 \%$ of the expected species from the survey area. Overall species richness was influenced by vegetation categories (Figure 3). Highest species richness (14 species) occurred in the sparse vegetation cover category followed by dense category (11) and the least (8 species) occurring on bare ground. Because species richness is positively correlated with sample size (Kindt and Coe, 2005), comparisons among vegetation categories could adequately be conducted considering 10 sites instead if 15 . In light of this, 12, 
10 and 8 species occurred on sparse, dense and bare ground respectively. At species level, Cubitermes spp.1, Macrotermes bellicosus, Macrotermes spp.2, Macrotermes spp.1 and Odontotermes spp. 2 were the most abundant species on grazing lands with total abundance of $142,66,55$, 48 and 46 respectively (Figure 4). At genus level, members of the genus Macrotermes were the most abundant species, followed by Cubitermes and Odontotermes. The total abundance of all members of Macrotermes, Cubitermes and Odontotermes was 236, 169 and 68 respectively. Trinervitermes oeconomus and Cubitermes spp. 3 were the least abundant species.

\section{DISCUSSION}

Composition of termite species: The survey yielded 16 termite species from eight genera and three subfamilies. Wood (1991) also noted that the dominant species in natural ecosystems belong to the subfamily Macrotermitinae, and include various species of Macrotermes, Odontotermes, Pseudacanthotermes, Ancistrotermes and Microtermes. Most of these termites are found throughout the savannas and wooded steppes of tropical Africa, below altitudes of 1800-2000 $\mathrm{m}$. The findings are also consistent with Sekamatte (2001) who noted that termites from two subfamilies (Macrotermitinae and Termitinae) were common species on grazing lands of Nakasongola ecosystem. Sekamatte (2001) further reported that members of the genera Cubitermes and Macrotermes were the most abundant termite species in Nakasongola rangelands while Nyeko and Olubayo (2005) observed that Macrotermes bellicosus and Macrotermes hyalinus dominated the termite assemblage structure in the rangelands of Tororo District in Uganda. The rare occurrence of termite species of the genus Trinervitermes could be attributed to the escalating denudation of grass cover due overgrazing and competition for resources with members of other genera. Trinervitermes species are specialist grass feeders and loss of adequate grass vegetation would deprive the species of adequate feed resources for survival. It is not surprising that the termite was only sampled from plots with dense grass cover.

The species composition of termite assemblages was noted to vary with vegetation cover categories. The changes were attributed to vegetation induced alternations in micro-climate, availability of feed resources as well as nesting sites. The observations are consistent with findings of Wood (1991) who noted that denudation of herbaceous and woody vegetation through overgrazing and deforestation respectively, destroyed the nests of species building small mounds (e.g. Trinervitermes) and those with shallow, subterranean nests (e.g. many soil feeders) leading to disappearance of species that depend on litter for nourishment. Bandeira et al. (2003), Jones et al. (2003) and Vasconcellos et al. (2010) also noted that the type of vegetation influenced the composition of termite assemblages while Lavell et al. (1997) showed significant declines in litter arthropod communities in savannas cleared of natural vegetation.

Feeding groups and nesting sites: Group II (Wood, litter and grass feeders) was the dominant feeding group on grazing lands in semi-arid Nakasongola. The group was dominated by species from the subfamily Macrotermitinae. These species are known to be generalist feeders and feed on various feed resources such as grass, wood, litter, and dung (Donovan et al., 2001 and Woods, 1991). Mitchell (2002) noted that generalist feeders such as members of the genera Macrotermes and Odontotermes are predominantly litter feeders. Once the species are deprived of sufficient amounts of litter or when the density of termite mounds is high, they resort to standing biomass and can consume more than $60 \%$ of the standing crop. In the current study, specialized grass feeders such as Trinervitermes oeconomus were very rare and this could be attributed to the low plant richness of the ground layer and the general patchiness of ground vegetation (Dawes-Gromadzki, 2008). Further, the deterioration of rangeland ecosystem attributable to overgrazing and indiscriminate tree cutting could have derived members of the sub-family Macrotermitinae of adequate litter for nourishment which in turn resorted to grass for survival. This scenario could have increased competition for grass between the specialized grass feeders and the generalist feeders and possibly the specialized grass harvesters were out competed. The study therefore reviled that the termite species in Nakasongola ecosystem are largely litter feeders but resort to herbaceous vegetation once deprived of adequate litter by inappropriate rangeland management practices such as overgrazing. This leads to the common perception that termites are the primary cause of denudation. Studies elsewhere have also shown that in the absence of overgrazing, the grass consumed by termites is insignificant and has no effect on subsequent grass production (Collins, 1980). Woods (1991) also noted that on overgrazed land in Ethiopia, the termites remove the remaining dry grass and grass litter leaving the soil bare and the false impression that they are the primary cause of denudation. Rangeland management practices that sustain availability of adequate feed resources (largely litter) would deter generalist feeders from destroying rangeland vegetation. 
Table I: Diversity and relative abundance (average no. of encounters per species for the two sampling periods) of termite species collected from three sites (ranches). Feeding groups are II = wood, litter and grass feeders; IV = true soil feeders. Nesting groups are: $\mathbf{w}$ $=$ nesting in wood; $h=$ hypogeal nests, $\mathrm{e}=$ epigeal mound, $\mathrm{a}=$ arboreal nest.

\begin{tabular}{|c|c|c|c|c|c|c|c|}
\hline \multirow[t]{2}{*}{ Termite species } & \multirow{2}{*}{$\begin{array}{l}\text { Feeding } \\
\text { group }\end{array}$} & \multirow{2}{*}{$\begin{array}{l}\text { Nesting } \\
\text { group }\end{array}$} & \multicolumn{2}{|c|}{ Kamukama Ranch } & \multicolumn{2}{|l|}{ Kyapapa Ranch } & Mandwa Ranch \\
\hline & & & Sparse & Dense & Sparse & Dense & Sparse \\
\hline
\end{tabular}

\section{TERMITIDAE}

Macrotermitinae

Macrotermes

(Smeathman)

Macrotermes herus

Macrotermes sp.1

Macrotermes sp.2

Macrotermes sp.3

Macrotermes sp. 4

Odontotermes sp. 1

Odontotermes sp. 2

Microtermes spp.

Ancistrotermes spp.

Pseudocanthotermes militaris II

$\begin{array}{ccc}\text { bellicosus } & \text { II } & \text { e } \\ & \text { II } & \text { e } \\ \text { II } & \text { e } \\ \text { II } & \text { W } \\ \text { II } & \text { a } \\ \text { II } & \text { h } \\ \text { II } & \text { W } \\ \text { II } & \text { h } \\ \text { II } & \mathrm{h} \\ \text { militaris II } & \mathrm{h}\end{array}$

e
e
w
a
h
w
h
h
h
w

$\begin{array}{ll}3.5 & 14 \\ 0 & 13 \\ 0 & 0 \\ 5.5 & 16 \\ 0 & 6 \\ 0 & 6 \\ 0 & 0 \\ 2.1 & 11 \\ 0 & 0 \\ 0 & 0 \\ 0 & 0\end{array}$

9
9
13
9
0
0
9
7
0
0
0

5.5
5
3.1
0
0
0
0
0
0
2.5
0

12
11
7
11
0
0
7
6
4
0
4

$\begin{array}{lll}5 & 5 & 1 \\ 0 & 0 & 2 \\ 0 & 10 & 4 \\ 10 & 0 & 0 \\ 0 & 0 & 0 \\ 4.2 & 0 & 0 \\ 0 & 0 & 0 \\ 6 & 5.2 & 0 \\ 0 & 0 & 0 \\ 4 & 0 & 0 \\ 0 & 0 & 0\end{array}$

Termitinae

Cubitermes sp.1

Cubitermes sp.2

Cubitermes sp.3

Procubitermes spp

$\begin{array}{ll}\text { IV } & \text { e } \\ \text { IV } & \text { h } \\ \text { IV } & \text { e } \\ \text { IV } & \text { e }\end{array}$

$\begin{array}{ll}0 & 46 \\ 2 & 0 \\ 0 & 0 \\ 0 & 4\end{array}$

0
8
0
0

5
0
2
0

$\begin{array}{llll}67 & 0 & 7 & 2 \\ 4.5 & 0 & 0 & 0 \\ 0 & 0 & 0 & 0 \\ 0 & 0 & 7 & 0\end{array}$

Nasutitermitinae

Trinervitermes

oeconomus IV

e

0

0

0

0

0

0

0

1.3 


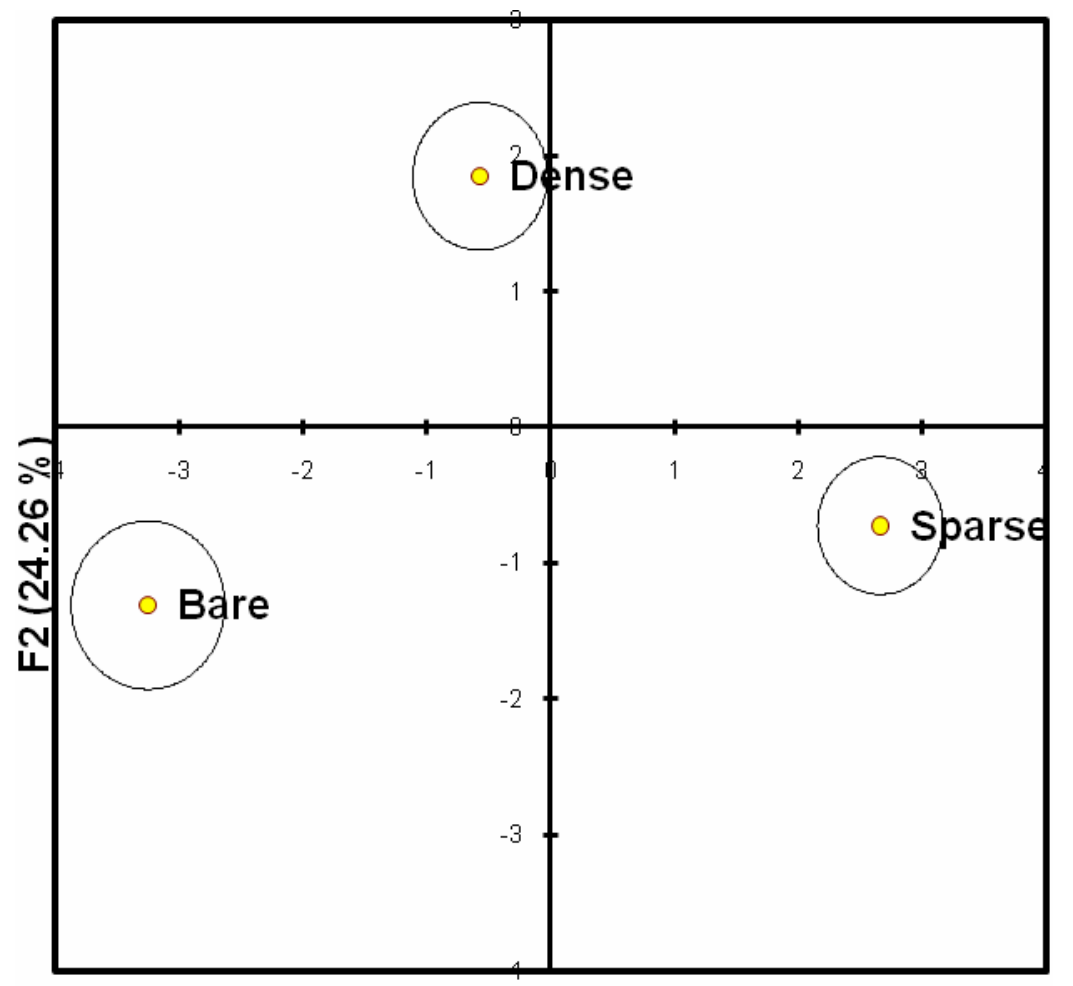

F1 $(75.74 \%)$

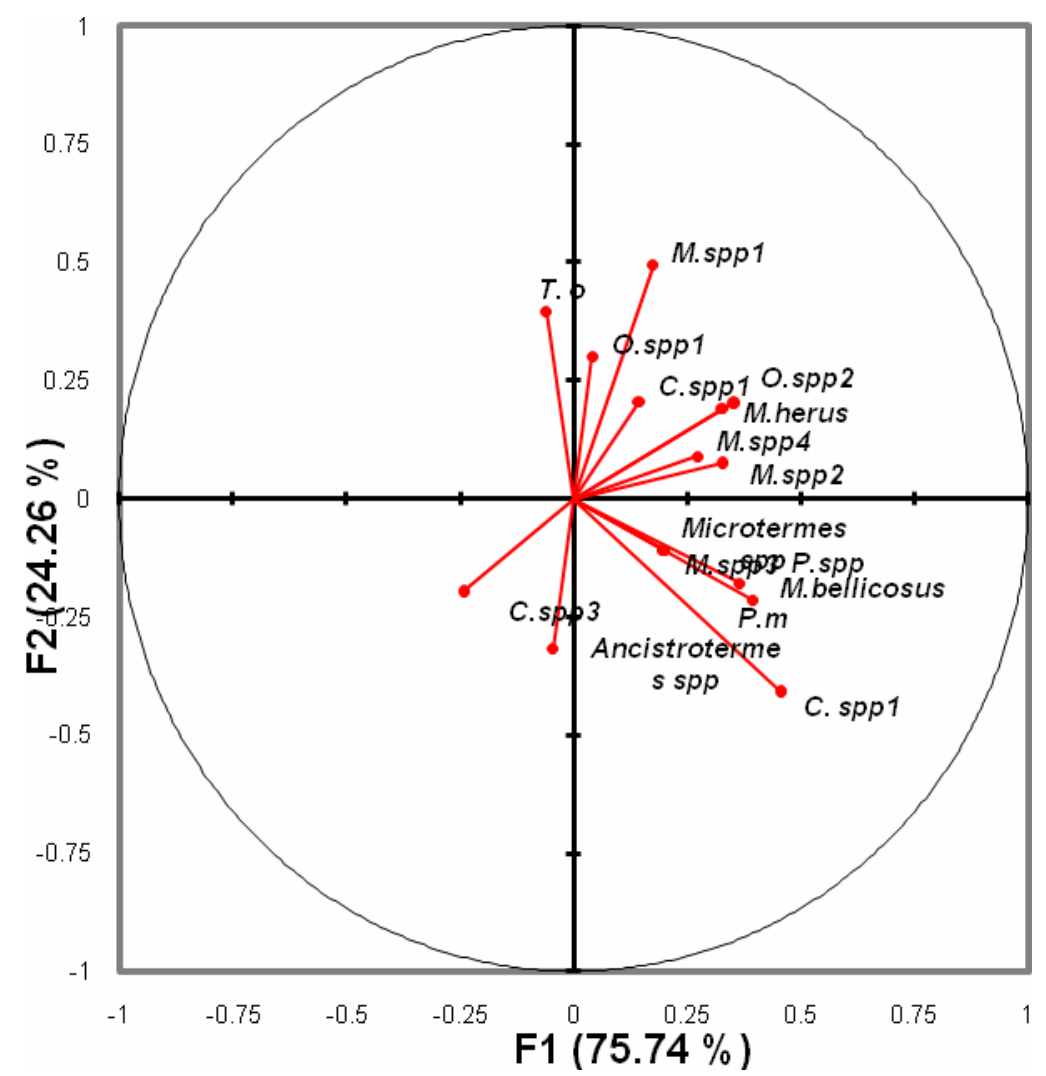

Fig 1: Discriminate analysis ordination graphs showing centroids (weighted averages) of vegetation categories and termite species (weighted averages of site scores). The eigenvalues of axis 1 (horizontally) and axis 2 (vertically) are 6.19 and 1.98 respectively. The species are Trinervitermes oeconomus (T.o), Macrotermes spp.1 (M.spp.1), Macrotermes spp.2 (M.spp.2), Macrotermes spp.3 (M.spp.3), Macrotermes spp.4 (M.spp.4), Odontotermes spp.1 (O.spp1), Odontotermes spp.2 (O.spp2), Cubitermes spp.1 (C. spp.1), Cubitermes spp.2 (C. spp.2), Cubitermes spp.3 (C. spp.3), Procubitermes spp (P.spp) and Pseudocanthotermes militaris (P.m). 
Agric. Biol. J. N. Am., 2011, 2(5): 848-859

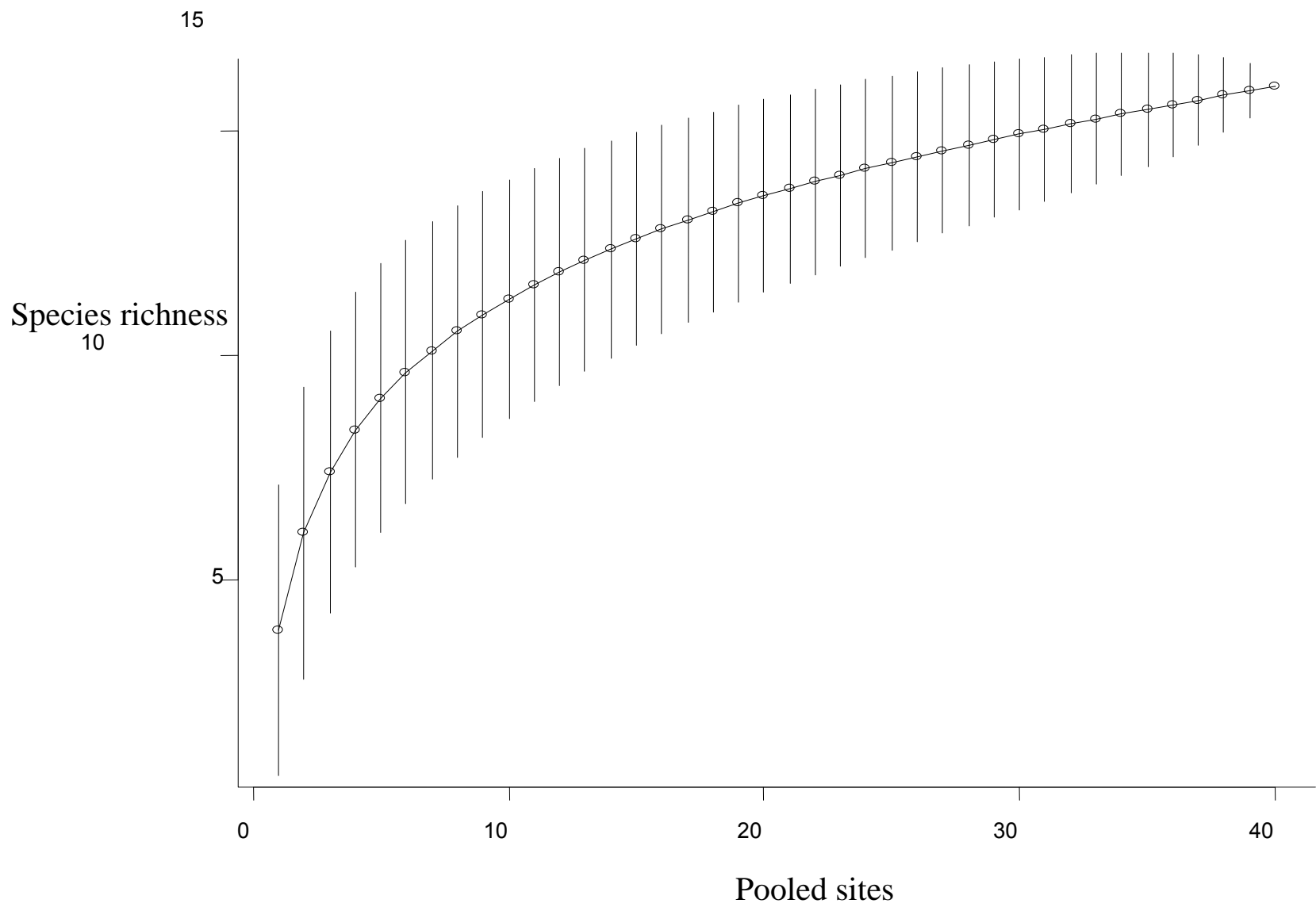

Fig 2: Species accumulation curve for termite species sampled from three ranches in Nakasongola. The bars indicate +2 and -2 standard deviations. 


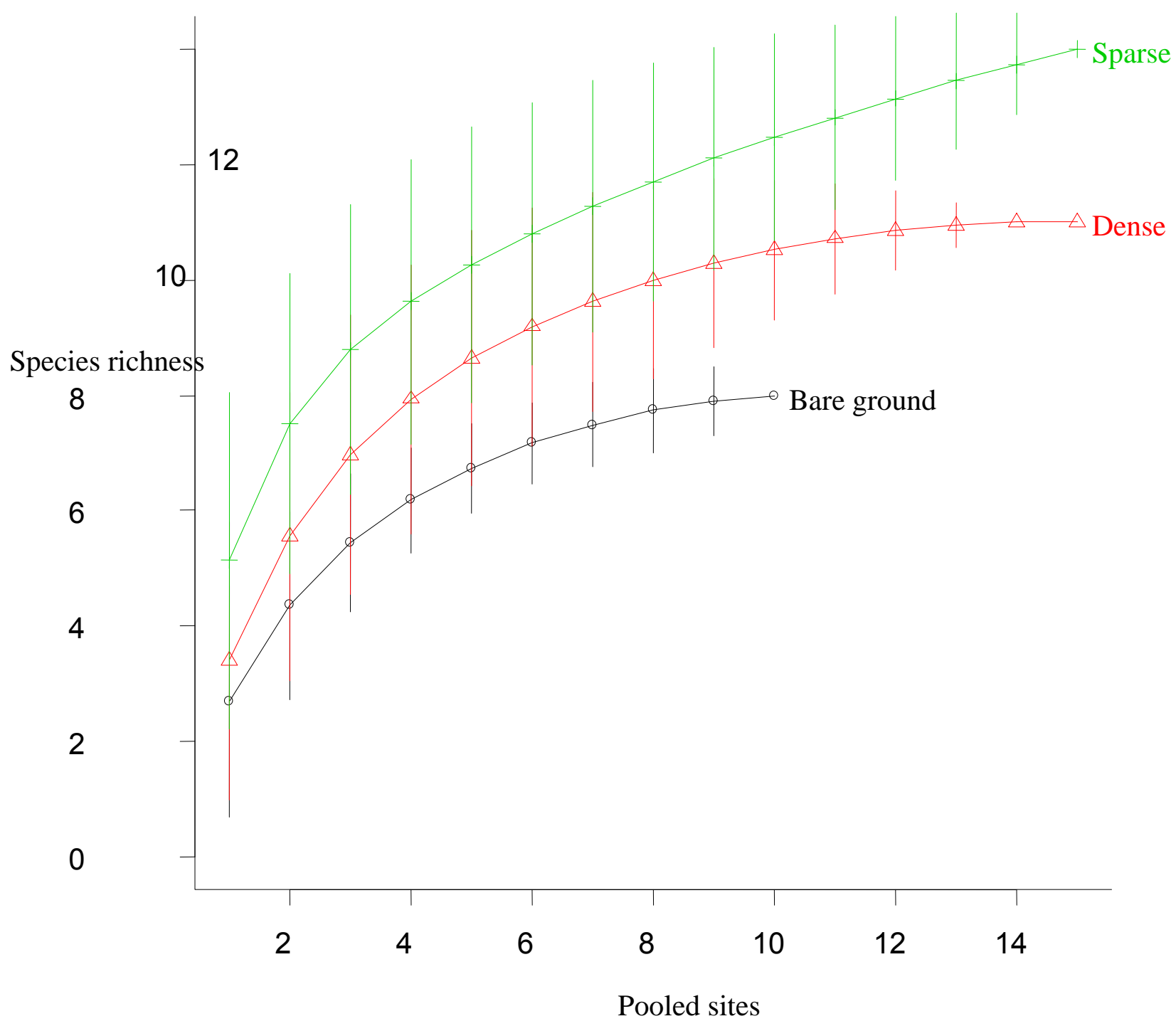

Fig 3: Species accumulation curves for termite species sampled from the three vegetation cover categories. The bars indicate +2 and -2 standard deviations. 
Agric. Biol. J. N. Am., 2011, 2(5): 848-859

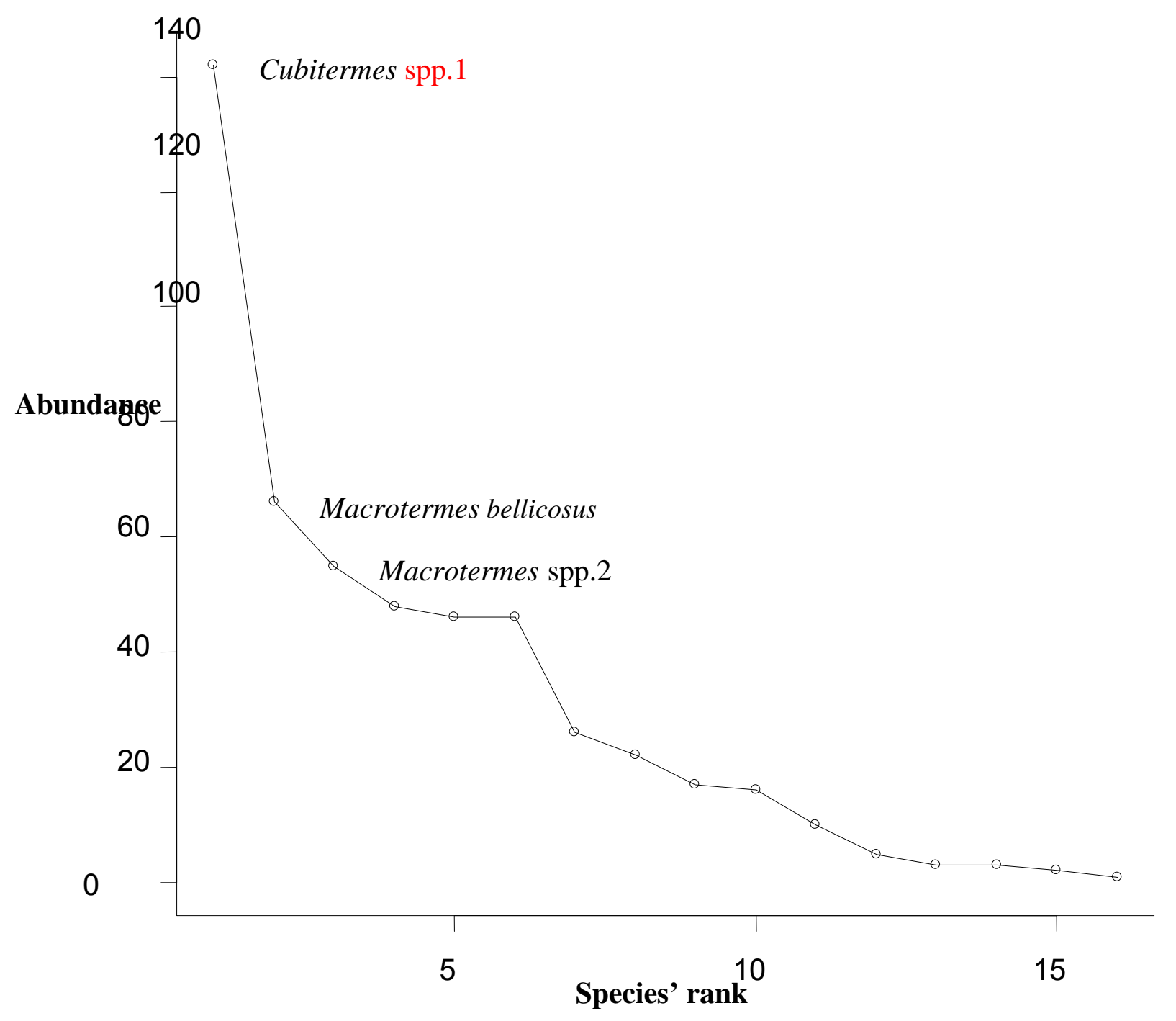

Fig 4: Rank-abundance curve for termite species sampled from three ranches in Nakasongola rangelands.

Epigeal-nesting species were the most common species followed by hypogeal-nesting species and this was attributed to the high termite encounter rates in mounds and lying dead wood. Dawes-Gromadzki (2008) also noted that epigeal nesting species were the most abundant species accounting for $88 \%$ of the total species in Savanna woodland reserve in Tropical Australia. Wood-nesting species were also represented but arboreal-nesting species were very rare. In fact, the arboreal nesting species was sampled twice during the sampling exercise. The epigeal nesters were dominated by Macrotermes and Cubitermes species. The number of epigeal mounds per hectare recorded in the current study is far above the average number of mounds in Uganda (1-4 ha $\left.{ }^{-1}\right)$ reported Pomeroy (1977). Pomeroy (1977) further noted that the greatest abundance of mounds in Uganda was 18.75 mounds ha- ${ }^{1}$. Okwakol and Sekamatte (2007) reported that the densities of large mounds of Macrotermitinae, which support millions of individuals, range between 2.02 per hectare and 13.25 per hectare and those of the smaller mounds of Cubitermes species to be 167 per hectare. This would give a maximum density of 180 mounds ha ${ }^{-1}$ for both Cubitermes species and members of the subfamily Macrotermitinae. This density is still below that observed in the current study. The results imply that the density of mounds and the subsequent populations of epigeal nesting species is on the rise and this posse a great threat to the remaining rangeland vegetation since the species are as well potential pests to vegetation. The increase in 
populations of epigeal nesting species could be partly attributed to loss predator mammals (such as Orycteropus afer) that tunnel into mounds to prey on all casts of termites. The mammals which used to constitute part of the biotic component of the ecosystem were lost due to hunting. Further, the deterioration of the ecosystem could have destroyed the nesting sites of insect predators such as ants that nest in litter. The combined effect of loss of mammal and insect predators could have led to proliferation of termites and the associated increase in mound construction.

Diversity: Based on the Jackknife second order estimate (23 species) of expected termite species in the survey area, the assemblage seems to be species poor. Although the survey added two new genera to the already existing inventory of termite genera on grazing lands in Nakasongola, one genus (Hodotermes) reported to occur on grazing lands (Sekamatte, 2001) was not represented. Lack of the genus could partly explain the missing species. Generally, fewer species occurred on bare surfaces as compared to dense and sparse vegetation categories. The possible explanation for this trend is that, removal of trees and denudation of basal vegetation attributed to indiscriminate tree cutting and overgrazing grazing respectively, affects the microclimate and the quantity and quality of feeding and nesting sites (Jones et al., 2003). This results in simplification of termite assemblages both in diversity and feeding groups. Bandeira et al. (2003) also noted that chopping down of trees increases the input of dead plant matter to the soil, this may increase populations of some termites, especially wood and leaf feeders. With time, the reduction of food resources, lack of soil cover and micro-climate changes may cause population reduction and local extinction (Bandeira et al., 2003). While comparing species richness between primary woodland, disturbed woodland and cleared areas, Vasconcellos et al. (2010) also noted that species richness was significantly lower on cleared areas than in the primary woodland. Unlike previous studies by Bandeeira et al. (2003) which showed that species richness reduced from the most preserved sites to the most disturbed sites. The findings from this study reviled that species richness was higher in the sparse vegetation category than in the dense category, which is known to be experiencing minimum disturbance. The species richness of a habitat is determined by a combination of abiotic environmental factors and biotic interactions such as competition and predation (Begon et al., 2006). The "intermediate disturbance hypothesis" states that habitats with intermediate levels of disturbance allow the maximum number of species to coexist; both competitive exclusion of species by competitive dominants at low disturbance, and persistence of only fugitive species at high disturbance are avoided (Connell, 1978; Abugov, 1982). Competitive co-existence of species that occupy different ecological niches in an ecosystem also generates high diversity (Abugov, 1982). Our results offers support for the intermediate disturbance hypothesis as termite species richness was highest in sparse vegetation cover category with intermediate levels of disturbance.

\section{CONCLUSION}

The survey yielded 16 termite species from eight genera, three sub-families and one family. Members of the genus Macrotermes were the most abundant species, followed by Cubitermes and Odontotermes. At species level, Cubitermes spp.1 and Macrotermes bellicosus were the most abundant species while Trinervitermes oeconomus and Cubitermes spp. 3 were the least abundant species. The termite assemblage comprised of two feeding groups namely Group II (Wood, litter and grass feeders) and Group IV (true soil feeders). Most of the species belonged to Group II. Apart from Trinervitermes oeconomus (specialized grass feeder), all the species that were assigned to Group II are known to be generalist feeders that predominantly feed on litter. Most of the species were noted to nest in epigeal and hypogeal nests with a few species nesting in wood. Vegetation cover categories were noted to influence species richness. Highest species richness occurred in sparse vegetation category followed by dense category and the least occurring on bare ground.

\section{ACKNOWLEDGEMENT}

We are grateful to RUFORUM (Regional Universities Forum for Capacity Building in Agriculture) and NaLIRRI (National Livestock Resources Research Institute, Uganda) for partially funding the study. We are also thankful to Dr. Chris Bakuneeta from the Department of Zoology, Makerere University for the overwhelming assistance in identification of termites.

\section{REFERENCES}

Abensperg-Traun, M (1991). Seasonal changes in activity of subterranean termite species (Isoptera) in Western Australian wheatbelt habitats. Australian Journal of Ecology 16, 331-336.

Abugov, $R$ (1982). Species diversity and phasing of disturbance. Ecology 63(2): 289-293. 
Bandeira, G. A., Vasconcellos, A., Silver, M and Constantino, $R$ (2003). Effects of habitat disturbance on the termite fauna in the highland humid forest in Caatinga domain, Brazil. Sociobiology 42, 117-127.

Begon, M., Harper, J.L and Townsend, C.R (2006). Ecology: from individuals to ecosystems, 4th Edition. Blackwell Publishing, Oxford, UK.

Collins, N. M (1980). The interaction and impact of domestic stock and termites in a Kenyan rangeland. In: The Biology of Social Insects. Breed, M. D., Michener, C. D and Evans, H. E (eds). Westview Press, Boulder, Colorado, 80-84.

Cowie, R. H. and Wood, T. G (1989). Termite damage to crops, forestry and rangeland in Ethiopia. Sociobiology $15,139-153$.

Dawes-Gromadzki, T. Z (2005). Bugs beneath the surface: the functional significance of soil macro invertebrates to landscape health in Australia's tropical savannas. Insect Science 12, 307-312.

Dawes-Gromadzki, T. Z (2008). Abundance and diversity of termites in a savanna woodland reserve in tropical Australia. Australian Journal of Entomology (2008) 47, 307-314.

Donovan, S. E., Eggleton, N. P and Bignell, D. E (2001). Gut content analysis and a new feeding group classification of termites. Ecological Entomology 26, 356-366.

Eggleton, P., Davies, R. G., Connetable, S., Bignell, D. E and Rouland, C (2002). The termites of the Mayombe Forest Reserve, Congo (Brazzaville): transect sampling reveals an extremely high diversity of ground nesting soil feeders. Journal of Natural History 36, 1239-1246.

Inoue, T., Takematsu, $Y$ and Hyodo, $F$ (2001). The abundance and biomass of subterranean termites (Isoptera) in a dry evergreen forest of northeast Thailand. Sociobiology 37, $41-52$.

Jones, D.T (2002). A survey of the termites (Insecta:Isoptera) of Tabalong District, South Kalimantan, Indonesia. Raffles Bulletin of Zoology 50, 117-128.

Huberty C. J (1994). Applied Discriminant Analysis. WileyInterscience, New York.

Jones, D.T., Susilo, F.X., Bignell, D.E., Hardiwinoto, S., Gillison, A.N and Eggleton, P (2003). Termite assemblage collapse along a land-use intensification gradient in lowland central Sumatra, Indonesia. Journal of Applied Ecology 40: 380-391.

Kindt, R and Coe, R (2005). Tree diversity analysis. A manual and software for common statistical methods for ecological and biodiversity studies. Nairobi: World Agroforestry Centre (ICRAF).

Lavelle, P., Bignell, D. E and Lepage, M (1997). Soil function in a changing world: the role of invertebrate ecosystem engineers. European Journal of Soil Biology 33, 159-193.
Mitchell, J. D (2002). Termites as pests of crops, forestry, rangeland and structures in southern Africa and their control. Sociobiology 40:47-69.

Mugerwa, S., Mpairwe, D., Sabiiti, E.N., Mutetikka, D., Kiwuwa, G., Zziwa, E and Peden, D (2008). Effect of cattle manure and reseeding on pasture productivity. Paper presented in the Challenge Programme on Water and Food" workshop held between $10^{\text {th }}-15^{\text {th }}$ November 2008, Addis Ababa, Ethiopia.

Nakasongola District State of Environment Report, 2004. Nakasongola District Council,http://www.nemaug.org.

National Environment Management Authority, 2007. State of the Environment Report for Uganda. NEMA, Kampala. 357pp.

Nyeko, P and Olubayo, F. M (2005). Participatory assessment of farmers' experiences of termite problems in agroforestry in Tororo district, Uganda. Agricultural Research and Extension Network Paper No. 143, Overseas Development Institute, London, UK

Obi, J. C and Ogunknle, O. A (2009). Influence of termite infestation on spatial variability of soil properties in the Guinea savanna region of Nigeria. Geoderma 148: 357363.

Oksanen, J., Kindt, R and O'Hara, R.B (2005). vegan: Community Ecology Package

version 1.6-9. http://cc.oulu.fi/ jarioksa/.

Okwakol, M. J. N and Sekamatte, M. B (2007). Soil macrofauna research in ecosystems in Uganda. Afr. J. Ecol., 45 (Suppl. 2), 2-8.

Pearce, M.J., Logan, J. W. M and Tiben, A (1995). Termites (Isoptera) from the Darfur region of the Sudan with comments on their pest status. Journalof Arid Environment 30:197-206.

R Development Core Team (2005). R: A language and environment for statistical computing.

R Foundation for Statistical Computing, Vienna, Austria. ISBN 3- 900051-07-0, URL http://www.R-project.org.

Sekamatte, M.B. 2001. Termite situation on crops and rangelands in Nakasongola District. A report submitted to the Environmental Protection and Economic Development (EPED) project, Kampala, Uganda.

Vasconcellos, A., Bandeira, G. A., Moura, S. F. M., Araujo, P. F. V., Gusmao, B. A. M and Constantino, R (2010). Termite assemblage in three habitats under different disturbance regimes in the semi-arid Caatinga of NE Brazil. Journal of Arid Environments 74 (2010) 298-302.

Webb, G.C (1991). Keys to the Genera of the African Termites. Ibadan University Press, Ibadan, Nigeria.

Wood, G. T. 1991. Termites in Ethiopia: The Environmental Impact of Their Damage and Resultant Control Measures. Ambio Vol. 20: No. 3-4.

XLSTAT, 2008: http://www.addinsoft.com. 